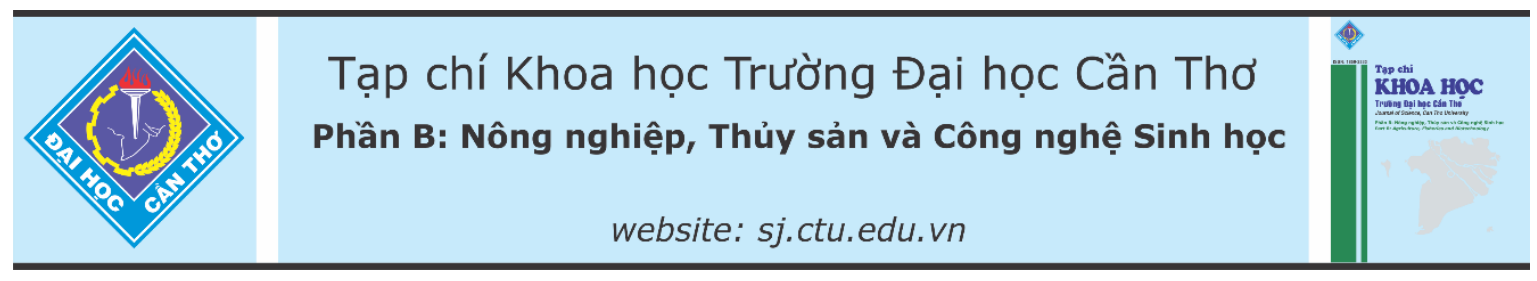

DOI:10.22144/ctu.jvn.2021.148

\title{
TİNH HİNH BỆNH DỊCH TẢ HEO CHÂU PHI VÀ ĐẠC ĐIỂM DI TRUYỀN CỦA VIRUS GÂY BỆNH Ở HUYỆN PHÚ TÂN, TỈNH AN GIANG
}

Hiến Thị Mỹ Trang ${ }^{1 *}$, Hồ Thị Việt Thu ${ }^{1}$, Nguyễn Đức Hiền ${ }^{2}$, Phạm Tiến Dũng $^{3}$ và

Nguyễn Phạm Thảo Nhi ${ }^{1}$

${ }^{1}$ Bộ môn Thú y, Khoa Nông nghiệp, Trường Đại học Cần Tho

${ }^{2}$ Chi cuc Chăn nuôi và Thú y thành phố Cần Tho

${ }^{3}$ Chi cục Thú y Vùng VI, thành phố Hồ Chí Minh

*Người chịu trách nhiệm về bài viết: Hiến Thị Mỹ Trang (email: trangm0319010@gstudent.ctu.edu.vn)

\section{Thông tin chung:}

Ngày nhận bài: $22 / 04 / 2021$

Ngày nhận bài sủa: 29/05/2021

Ngày duyệt đăng: 29/10/2021

Title:

Epidemiology and genetic characteristics of African swine fever viruses in Phu Tan dictrict, An Giang province

\section{Tù khóa:}

Dịch tả heo Châu Phi, dịch têe, kiểu gene, Phú Tân

\section{Keywords:}

African swine fever, epidemiology, genotype, Phu Tan district

\begin{abstract}
African swine fever (ASF) outbreaks firstly appeared in Phu Tan dictrict, An Giang province in July 2019, then outbreaks were reported from all 18 towns and villages of Phu Tan district. This study was carried out to survey some epidemiological characteristics of ASF and ASFV (African swine fever virus) genotype which have circulated in this region. The results from retrospective survey indicated that ASF happened in 163 out of 546 pig farms (29.85\%), and $27.37 \%$ of pig population was destroyed. There were differences of destruction by pig categories, the high destruction was reported in breeding herds, in which the highest rate was on boars (100\%), followed by sows (34.24\%), growing pigs (26.83\%), and the lowest was on piglets (24.96\%). Genetic characteristics of ASFV were based on by partial genome sequencing of the B646L (p72) gene from 4 ASFV representative strains, the result showed that their sequences were 100\% homologous with that of viruses previously detected in Vietnam, China and they all belonged to genotype II.
\end{abstract}

\section{TÓM TẮT}

Bệnh dịch tả heo Châu Phi (ASF) xảy ra lần đầu tiên ở huyện Phú Tân, tỉnh An Giang vào tháng 7/2019 và nhanh chóng lây lan khắp 18/18 xã và thị trấn trên địa bàn huyện. Nghiên cưu được thực hiện nhằm khảo sát một số đặc điểm dịch tễ và kiểu gene của virus gây bệnh ASF. Kết quả điều tra hồi cứu thông qua các sổ liệu được thu thập tù các báo cáo của các cơ quan có thẩm quyền cho thấy tỷ lệ các cơ sở xuất hiện ASF là $29,85 \%$ và tỷ lệ heo bị tiêu hủy là 27,37\%. Có sụ khác biệt về tỷ lệ tiêu hủy theo loại heo, trong đó tỷ lẹ tiêu hủy cao trên heo giống sinh sản, cao nhất là trên heo đục giống (100\%), kế đến là heo nái (34,24\%), heo thịt (26,83\%) và thấp nhất là heo con (24,96\%). Đặc điểm di truyền của virus ASF luu hành tại huyện Phú Tân được khảo sát trên cơ sở một phần của đoạn gene B646L (p72) của 4 chủng virus đại diện, kết quả cho thấy đoạn gene 72 của 4 chủng virus được phát hiện tại huyện Phú Tân tuoong đồng $100 \%$ vớ đoạn gene tuoong úng của các chủng virus đã được phát hiện truớc đó tại Việt Nam, Trung Quốc và cùng thuộc genotype II. 


\section{GIỚI THIẸU}

Bệnh dịch tả heo Châu Phi (ASF - African swine fever) là bệnh truyền nhiễm nguy hiểm trên heo, bệnh lần đầu tiên được báo cáo bởi Montgomery ở Kenya vào năm 1921, sau đó, bệnh xảy ra dạng dịch bệnh địa phương của nhiều nước Châu $\mathrm{Phi}$ (Montgomery, 1921). Bệnh do virus (ASFV African swine fever virus) thuộc họ Asfarviridae, giống Asfivirus có vật chất di truyền dạng DNA sợi kép kích thước 170 đến 193 kbp (Dixon et al., 2005). Tất cả 24 kiểu gene ASFV đã biết được xác định ở tiểu vùng Sahara Châu Phi (Quembo et al., 2017). Khi phân tích cây phát sinh loài của các chủng ASFV dựa trên các vùng gene khác nhau cho thấy có sự khác nhau giữa các chủng ASFV phân lập được (Bastos et al., 2003). Kết quả phân tích các chủng $\mathrm{ASFV}$ đã chứng minh rằng gene $\mathrm{B} 646 \mathrm{~L}$ (mã hóa một trong các protein cấu trúc chính, p72) đã xác định được 13 kiểu gene phân lập được ở tám quốc gia Đông Phi (Lubisi et al., 2005) và 6 kiểu gene mới phân lập ở miền Nam Châu Phi (Boshoff et al., 2007).

ASF xảy ra trên mọi lứa tuổi và loài heo từ heo nhà đến heo rừng, với đặc điểm lây lan nhanh và tỷ lệ chết cao lên đến $100 \%$ (Zsak et al., 2005). Ở nước ta bệnh chỉ mới xuất hiện lần đầu tiên là vào tháng 02/2019 tại hai tỉnh Hưng Yên và Thái Bình, sau đó 63/63 tỉnh thành trên cả nước đều xuất hiện ASF. Kết quả nghiên cứu của Van Phan Le et al. (2019) cho thấy ASFV ở Việt Nam được phát hiện là VNUA/HY-ASF1 thuộc kiểu geneotype II và tương đồng 100\% với các chủng Trung Quốc, Georgia, Nga, Estonia và Ba Lan. Tỉnh An Giang ghi nhận ca nhiễm ASF đầu tiên vào tháng $5 / 2019$, toàn tỉnh hiện có 11 huyện, thị xã và thành phố công bố dịch ASF. Trong đó, huyện Phú Tân ghi nhận ổ dịch ASF đầu tiên là vào tháng 7/2019 tại một cơ sở chăn nuôi heo nông hộ ở xã Long Hòa và là địa phương thứ 5 trên địa bàn tỉnh xuất hiện ASF. Tính từ thời điểm xuất hiện ổ dịch đầu tiên đến khi công bố hết dịch vào ngày $06 / 01 / 2020$, toàn huyện buộc phải tiêu hủy 2.907 con heo, tổng thiệt hại lên đến $27 \%$ tổng sản lượng đàn heo cả huyện và ảnh hưởng rất lớn đối với ngành chăn nuôi huyện Phú Tân, đặc biệt là một bộ phận người chăn nuôi heo (Trạm Chăn nuôi và Thú y Phú Tân, 2019). Nghiên cứu này được thực hiện nhằm xác định đặc điểm dịch tễ bệnh $\mathrm{ASF}$ và kiểu gene của virus ASFV lưu hành trên đàn heo ở huyện Phú Tân, tỉnh An Giang.

\section{NỘI DUNG VÀ PHƯƠNG PHÁP NGHHÎ̂N CÚU}

\subsection{Vật liệu}

Tất cả 163 cơ sở chăn nuôi heo có kêt quả xét nghiệm dương tính với bệnh $\mathrm{ASF}$ và 4 mẫu $\mathrm{ADN}$ từ 4 mẫu bệnh phẩm trên đàn heo có kết quả xét nghiệm dương tính với $\mathrm{ASFV}$ thuộc bốn xã: Phú Lâm, Chợ Vàm, Phú Mỹ và Phú Long ở huyện Phú Tân, tỉnh An Giang.

\subsection{Phương pháp nghiên cứu}

\subsubsection{Phuoong pháp điều tra tình hình bệnh $A S F$}

Phương pháp điều tra: điều tra hồi cứu để thu thập thông tin tình hình dịch bệnh ASF trên địa bàn huyện Phú Tân từ khi có ổ dịch đầu tiên vào ngày 13/7/2019 đến khi công bố hết dịch ngày 06/01/2020, bao gồm những thông tin cần thiết, như: tổng đàn heo, địa điểm xảy ra ổ dịch, thời gian xuất hiện ổ dịch, loại heo nhiễm bệnh, số heo tiêu hủy,... đồng thời tham chiếu với kết quả xét nghiệm PCR, và tổng hợp các báo cáo về ổ dịch của Trạm Chăn nuôi và Thú y huyện Phú Tân, báo cáo tổng hợp của Chi cục Chăn nuôi và Thú y tỉnh An Giang trong thời gian xảy ra dịch bệnh để phân tích số liệu. Xác định tỷ lệ các cơ sở xảy ra ASF và sự phân bố các ổ dịch ở các xã, thị trấn trên địa bàn huyện Phú Tân.

\subsubsection{Phuơng pháp khảo sát đặc điểm gene ASFV}

Bốn chủng ASFV (có giá trị Ct thấp nhất) đại diện từ 4 địa phương là xã Phú Lâm (VN/Pig/PLAM3664), xã Phú Long (VN/Pig/PLONG/3882); thị trấn Chợ Vàm (VN/Pig/CVAM/3669) và thị trấn Phú Mỹ (VN/Pig/PMY/4084), có được từ kết quả phản ứng realtime PCR sử dụng cặp mồi dựa trên nghiên cứu trước đó của King et al. (2003) (theo khuyến cáo của OIE, 2019), được tiếp tục sử dụng cho phản ứng PCR truyền thống để tổng hợp một phần đoạn gene B646L (p72) dùng để xác định kiểu gene của virus ASFV. Sản phẩm PCR chứa đoạn gene đích $\mathrm{p} 72$ được tinh sạch bằng bộ kít TopPURE ${ }^{\circledR} \mathrm{PCR} / \mathrm{Gel}$ DNA Purification Kit (Việt Nam). Sau khi tinh sạch, tất cả sản phẩm được gửi đến công ty Nam Khoa để giải trình tự bằng phương pháp Sanger sử dụng cặp mồi tương ứng bằng bộ kít $\mathrm{ABI}$ Prism $\mathrm{BigDye}^{\mathrm{TM}}$ Terminator v1.1 Cycle Sequencing trên máy giải trình tự tự động $\mathrm{ABI}$ PRISM 3500.

Kết quả giải trình tự đoạn gene p72 được thể hiện và kiểm tra trên phần mềm BioEdit 2000, độ tương đồng của đoạn gene được so sánh với các trình tự khác trên Ngân hàng gene của NCBI (National Center for Biotechnology Information) bằng công cụ BLAST. Trình tự của gene p72 đại diện cho 24 
kiểu gene của ASFV được chọn lọc trên ngân hàng gene và được sử dụng để so sánh cặp (multialignment) bằng phương pháp Clustal $\mathrm{W}$ (Thompson et al., 1997). Kiểu gene của virus ASFV khảo sát được xác định qua mức độ tương đồng trên cây phả hệ được xây dựng theo phương pháp maximum likelihood với bootstrap 1.000 lần lặp lại trên phần mềm MEGA 7.0

\section{KẾT QUẢ VÀ THẢO LUẬN}

3.1. Tình hình bệnh ASF trên đàn heo ở huyện Phú Tân, tỉnh An Giang

3.1.1. Tỷ lệ heo tiêu hủy do nhiếm ASF

Bảng 4. Số liệu các ổ dịch ASF ở các xã, thị trấn trên địa bàn huyện Phú Tân

\begin{tabular}{llcccrrr}
\hline Stt & Xã, thị trấn & $\begin{array}{c}\text { Tổng số } \\
\text { sở } \\
\text { chăn } \\
\text { nuôi }\end{array}$ & $\begin{array}{c}\text { Số co sở } \\
\text { chăn nuôi } \\
\text { có dịch }\end{array}$ & $\begin{array}{c}\text { Tỷ lệ } \\
(\%)\end{array}$ & $\begin{array}{c}\text { Tổng đàn } \\
\text { (con) }\end{array}$ & $\begin{array}{c}\text { Số heo tiêu } \\
\text { hủy do } \\
\text { ASF (con) }\end{array}$ & $\begin{array}{r}\text { Tỷ lệ } \\
\text { (\%) }\end{array}$ \\
\hline 1 & Xã Long Hòa & 24 & 10 & 41,67 & 659 & 159 & 24,13 \\
2 & Xã Phú Lâm & 65 & 42 & 64,62 & 1.135 & 522 & 45,99 \\
3 & Xã Phú Thạnh & 39 & 18 & 46,15 & 841 & 241 & 28,66 \\
4 & Thị trấn Chợ Vàm & 52 & 25 & 48,08 & 992 & 354 & 35,69 \\
5 & Xã Phú An & 29 & 4 & 13,79 & 264 & 29 & 10,98 \\
6 & Xã Phú Thọ & 22 & 5 & 22,73 & 311 & 58 & 18,65 \\
7 & Thị trấn Phú Mỹ & 22 & 5 & 22,73 & 429 & 100 & 23,31 \\
8 & Xã Tân Hòa & 22 & 4 & 18,18 & 735 & 400 & 54,42 \\
9 & Xã Tân Trung & 30 & 7 & 23,33 & 577 & 65 & 11,27 \\
10 & Xã Bình Thạnh Đông & 49 & 10 & 20,41 & 897 & 606 & 67,56 \\
11 & Xã Phú Bình & 17 & 4 & 23,53 & 289 & 35 & 12,11 \\
12 & Xã Hòa Lạc & 26 & 2 & 7,69 & 472 & 42 & 8,90 \\
13 & Xã Phú Hiệp & 4 & 1 & 25,00 & 89 & 8 & 8,99 \\
14 & Xã Phú Hưng & 42 & 9 & 21,43 & 665 & 92 & 13,83 \\
15 & Xã Hiệp Xương & 17 & 2 & 11,76 & 599 & 17 & 2,84 \\
16 & Xã Phú Xuân & 16 & 3 & 18,75 & 371 & 20 & 5,39 \\
17 & Xã Phú Thành & 24 & 10 & 41,67 & 408 & 130 & 31,86 \\
18 & Xã Phú Long & 46 & 2 & 4,35 & 889 & 29 & 3,26 \\
\hline & Tổng cộng & 546 & 163 & 29,85 & 10.622 & 2.907 & 27,37 \\
\hline
\end{tabular}

Nguồn: Trạm Chăn nuôi và Thú y huyện Phú Tân (2019a, 2019b)

Từ khi ghi nhận ca nhiễm ASF đầu tiên đến khi công bố hết dịch, trên địa bàn huyện Phú Tân đã có 163 cơ sở chăn nuôi heo xảy ra bệnh $\mathrm{ASF}$ và $18 / 18$ xã, thị trấn đều công bố dịch. Tỷ lệ cơ sở nhiễm ASF ở huyện Phú Tân là $29,85 \%$ và buộc phải tiêu hủy 2.907 con, tỷ lệ này thấp hơn so với nghiên cứu của Trần Thanh Dũng (2020), tỷ lệ cơ sở ASF trên địa bàn huyện Long Mỹ, tỉnh Hậu Giang là 43,3\% và địa phương buộc phải tiến hành tiêu hủy hơn 20.000 con heo, tương đương 1.200 tấn heo hơi.

Kết quả trình bày ở Bảng 4 cho thấy tổng số heo tiêu hủy toàn huyện là rất lớn, lên đến 2.907 con chiếm 27,37\% tống đàn heo của huyện. Xã Bình Thạnh Đông có số lượng heo tiêu hủy cao nhất huyện chiếm $67,56 \%$ sản lượng đàn heo của xã, kế đến là xã Tân Hòa tiêu hủy 400 con chiếm tỷ lệ
$54,42 \%$ và xã có tỷ lệ tiêu hủy thấp nhất là xã Phú Long chỉ tiêu hủy 29 con trên tổng đàn heo của xã chiếm tỷ lệ 3,26\%. Mặc dù xã Tân Hòa và xã Bình Thạnh Đông có số hộ nhiễm ASF thấp nhưng số lượng tiêu hủy cao nhất huyện, nguyên nhân là vì ở hai địa phương này có cơ sở chăn nuôi với quy mô lớn của huyện và là những cơ sở nhiễm ASF trong giai đoạn đầu của huyện (một cơ sở ở xã Tân Hòa là 190 con và một cơ sở ở xã Bình Thạnh Đông là 217 con, có kết quả dương tính ngày 14/7/2019). Theo Quyết định số 4527/QĐ-BNN-TY ngày 15/11/2018 của Bộ Nông nghiệp và Phát triển nông thôn về việc Ban hành Kế hoạch hành động ứng phó khẩn cấp với bệnh ASF, đối với địa phương lần đầu tiên phát hiện heo bị bệnh ASF buộc phải tiêu hủy toàn đàn trong vong 24 giờ kể từ khi có kết quả xét nghiệm dương tính với bệnh $\mathrm{ASF}$. 


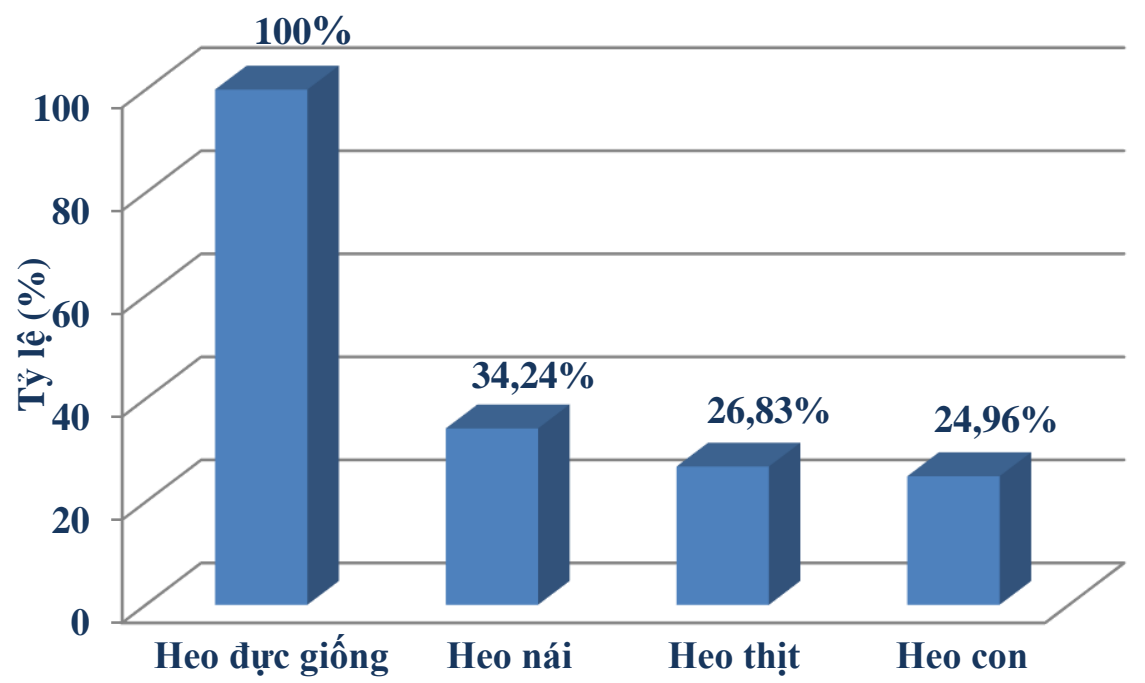

Hình 1. Số heo tiêu hủy do nhiễm ASF trên từng loại heo ở huyện Phú Tân

Kết quả phân tích tỷ lệ tiêu hủy do ASFV gây ra trên các đối tượng heo nuôi khác nhau để đánh giá tình hình bệnh theo loại heo từ Hình 1 cho thấy tỷ lệ cao nhất trên heo đực giống là $100 \%$ (13/13 con), kế đến là heo nái là $34,24 \%(427 / 1.247$ con $)$, heo thị là $26,83 \%(1.866 / 6.954$ con) và thấp nhất là trên heo con $24,96 \%$ (601/2.408 con). Kết quả này hoàn toàn phù hợp với nghiên cứu của Trương Văn Hiểu và ctv. (2020). Hầu hết các nghiên cứu về ASF đều cho thấy mọi lứa tuổi heo đều cảm nhiễm (BeltránAlcrudo et al., 2017; Phan Thị Hồng Phúc và ctv., 2020; Trương Văn Hiểu và ctv., 2020) nhưng chưa có báo cáo nào nghiên cứu về tính cảm nhiễm đối với $\mathrm{ASFV}$ trên từng lứa tuổi heo. Bên cạnh đó, tế bào đích của ASFV là các tế bào bạch cầu đơn nhân và đại thực bào, chúng xâm nhập vào tế bào theo cơ chế bám thụ thể và nội thực bào, virus nhân lên ở vùng rìa nhân của tế bào chủ và thoát ra khỏi tế bào theo cơ chế nảy chồi và gây chết tế bào (Alcamí et al., 1989), nên tỷ lệ lây nhiễm ASF cao ở heo đực giống và heo nái vì ở các động vật này đã trưởng thành nên số lượng tế bào đích mà ASFV hướng đến đã hoàn thiện và phù hợp với sự nhân lên của virus. Đồng thời, ở hai đối tượng heo đực giống và heo nái thì nguy cơ nhiễm bệnh nhiều hơn do người lấy tinh, người dẫn tinh, đưa đi phối giống trực tiếp, tiếp xúc với con cái, hoặc sử dụng phụ phế phẩm làm thức ăn chăn nuôi nhiều hơn,...Nên những loại heo này thường phát bệnh trước tiên. ASF là bệnh mới xuất hiện, do đó bệnh sẽ có mức độ lây lan nhanh.

\subsubsection{Sự phân bố ASF theo cấp độ xã}

Đặc điểm dịch tễ học không gian tất cả các ổ dịch ASF tại huyện Phú Tân từ bản đồ phân bố dịch Hình
2 cho thây các xã ở khu vực Sông Tiền có tỷ lệ nhiễm ASF rất cao, xã Phú Lâm có tỷ lệ nhiễm ASF cao nhất huyện; tiếp đến là thị trấn Chợ Vàm và xã Phú Thạnh. Ở các địa phương này đa số tập trung các cơ sở chăn nuôi nhỏ lẻ, số lượng nuôi ít và mật độ nuôi cao, phương thức chăn nuôi chưa phù hợp (nhiều hộ nuôi thành cụm), điều kiện chăm sóc nuôi dưỡng chưa đảm bảo an toàn dịch bệnh như tận dụng diện tích nhà ở để làm khu vực nuôi, tận dụng thức ăn thừa từ hàng quán và các hộ gia đình; nguồn nước sử dụng trực tiếp từ nguồn nước sông không qua xử lý lắng lọc hay khử trùng, ít thực hiện vệ sinh tiêu độc sát trùng chuồng trại, khu vực chăn nuôi thường xuyên có người ra vào chuồng, điều kiện chuồng nuôi ẩm thấp. Đặc biệt, xã Phú Lâm là điểm có số lượng cơ sở giết mổ tập trung thứ 2 của huyện, đồng thời có số chợ mua bán động vật tập trung lớn thứ 2 sau thị trấn Phú Mỹ và giáp ranh tỉnh Đồng Tháp đã công bố dịch $\mathrm{ASF}$ vào tháng $5 / 2019$, xã Phú Lâm (thuộc huyện Phú Tân, tỉnh An Giang) cách tỉnh Đồng Tháp bởi con Sông Tiền nên nguy cơ lây lan dịch bệnh qua nguồn nước là rất cao vì nguồn nước sử dụng chủ yếu vào chăn nuôi ở địa phương chủ yếu sử dụng trực tiếp nguồn nước sông để tiết kiệm chi phí, vì thế ở xã Phú Lâm bùng phát dịch bệnh rất cao và lây lan trong diện rộng đến 42/65 cơ sở chăn nuôi heo bị nhiễm ASF. Tỷ lệ nhiễm thấp nhất là các xã Hòa Lạc, xã Phú Hiệp, xã Hiệp Xương, xã Phú Xuân và xã Phú Long, đây là vùng cách xa khu vực trung tâm và có diện tích đất rộng, người thưa với quy mô và số lượng chiếm tỷ lệ khá cao. Thêm vào đó, $\mathrm{ASF}$ ở các địa phương này xảy ra sau nên người chătậpn nuôi có ý thức bảo vệ và phòng bệnh cho vật nuôi tốt hơn như: tiêm phòng đầy đủ các bệnh 
truyền nhiễm, định kỳ vệ sinh tiêu độc sát trùng chuồng trại 2 lần/tuần và đặc biệt chăn nuôi là nguồn thu nhập chính nên dịch bệnh được người chăn nuôi rất quan tâm.

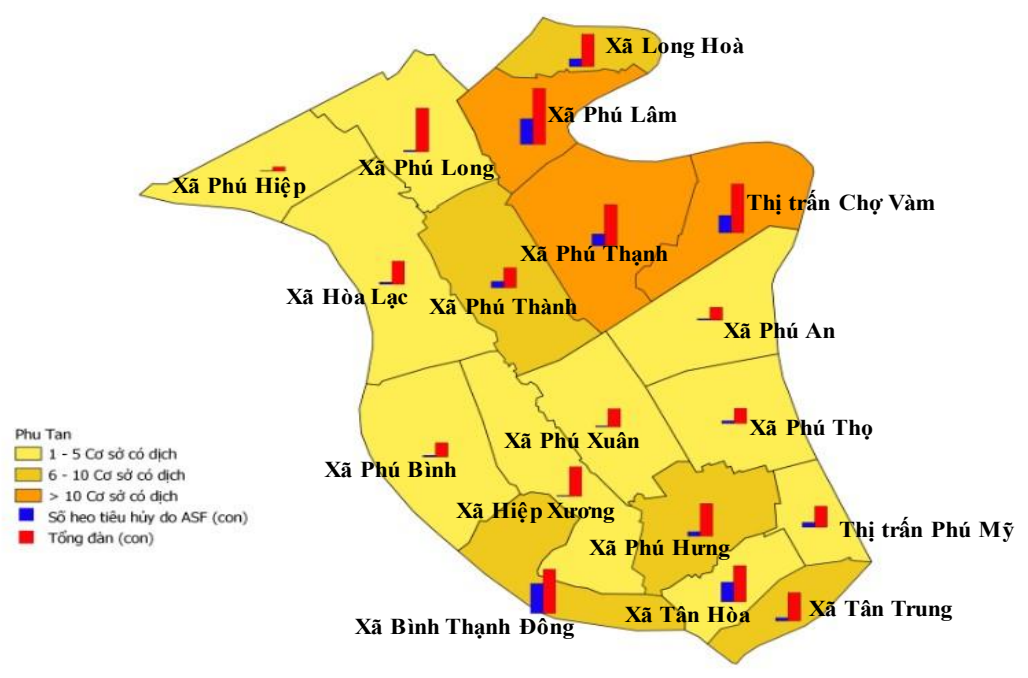

Hình 2. Bản đồ phân bố dịch theo cấp độ xã tại huyện phú Tân, tỉnh An Giang

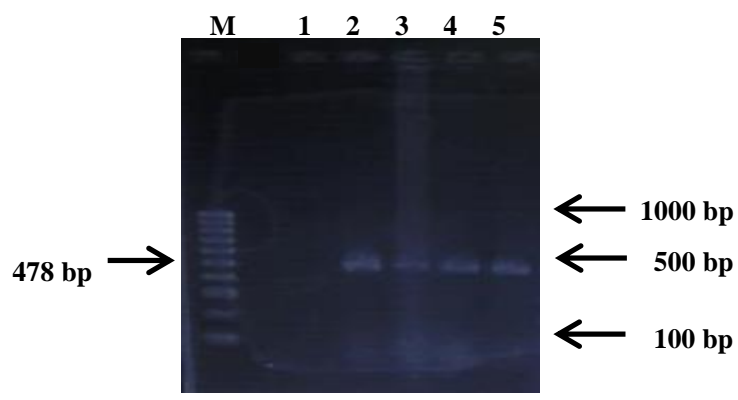

Hình 3. Kết quả khuếch đại đoạn gene p72 bằng phản ứng PCR

Giếng M: Thuớc đo 1000bp; Giếng 1: Mẫu đối chứng âm (-); Giếng 2: Mẫu (+) xã Phú Long;

Giếng 3: Mẫu (+) xã Phú Lâm; Giếng 4: Mẫu (+) thị trấn Phú Mỹ ; Giếng 5: Mẫu (+) thị trấn Chọ Vàm;

\section{2. Đặc điểm gene của $\mathrm{ASFV}$ lưu hành tại} huyện Phú Tân, tỉnh An Giang

Để xác định kiểu gene của ASFV lưu hành ở huyện Phú Tân, tỉnh An Giang, cây di truyền phả hệ dựa trên trình tự nucleotide của đoạn gene p72 của bốn chủng ASFV đã được thiết lập với 10 chủng $\mathrm{ASFV}$ đã được phát hiện trước đó tại Việt Nam và 29 chủng ASFV tham khảo trên thế giới. Trong đó có 24 chủng được tham khảo từ nghiên cứu phân loại kiểu gene (Quembo et al., 2018), là các nhánh phân bố các quốc gia Châu Phi, một chủng từ vùng Irkutsk của Nga (KY963545.1_Irkutsk-2017), một chủng của Trung Quốc MN172368.1_ASFV/Pig/China/CAS19-01/2019), một chủng của Triều Tiên (MN603967.1_Korea/Pig/Paju1/2019), và một chủng của Hàn Quốc (MN817977_South Korea/19s804/2019). 


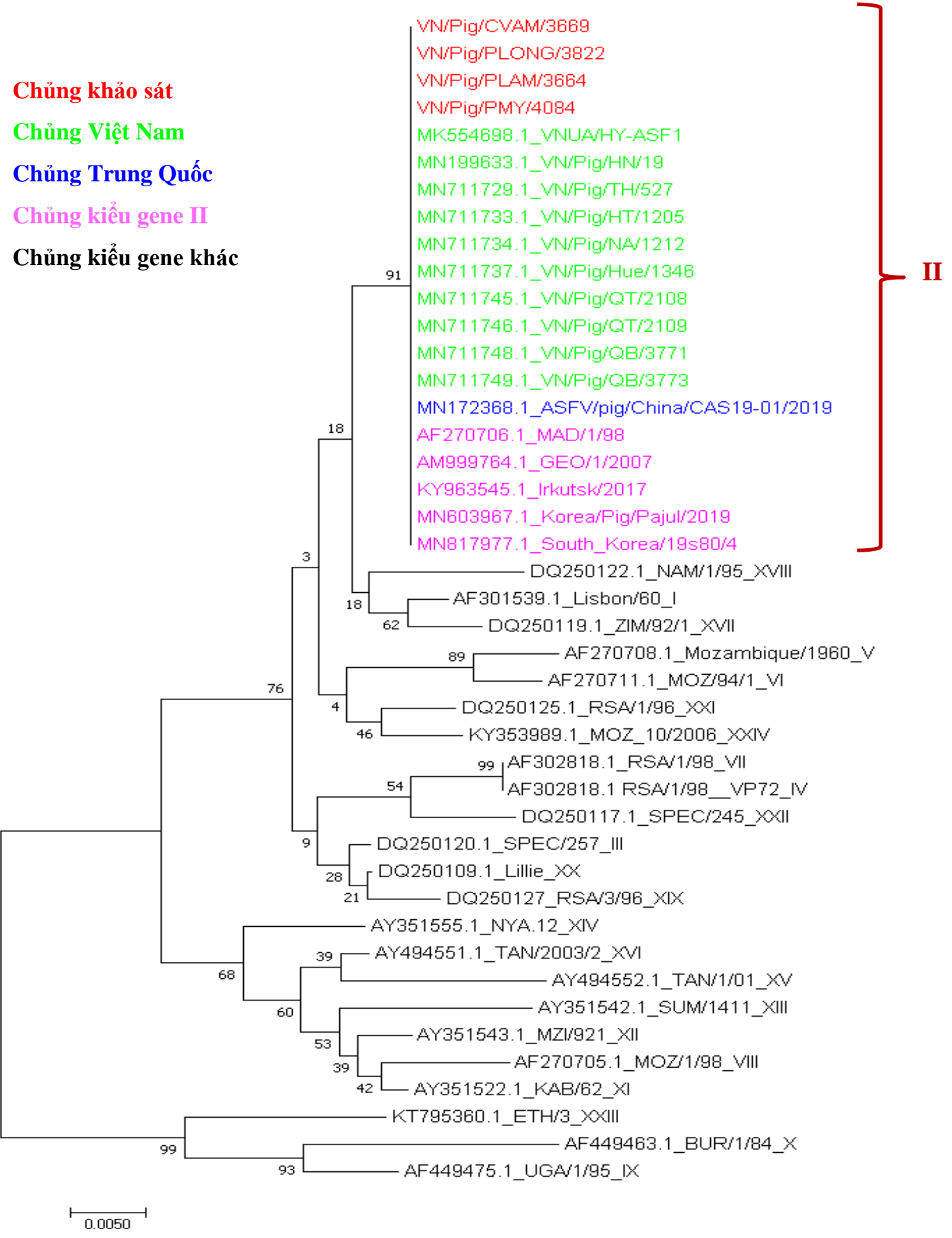

Hình 4. Cây phả hệ phát sinh loài dựa trên đoạn gene p72 của các chủng virus khảo sát và các chủng tham chiếu

Ghi chú: chĩ số la mã tù I - XXIV phía sau tên chủng ASFV là kiểu gene 
Hình 4 cho thấy 4 chủng ASFV (VN/Pig/ CVAM/3669, VN/Pig/PLONG/3882, VN/Pig/ PLAM3664, VN/Pig/PMY/4084) lưu hành tại huyện Phú Tân, tỉnh An Giang có kiểu gene cùng phân nhánh với các chủng ASFV trước đó được phát hiện tại Việt Nam, tiêu biểu là kiểu gene chủng ở Hưng Yên và có thể nói cho đến nay các kiểu gene ASFV xuất hiện ở Việt Nam đều thuộc kiểu gene II. Đồng thời, các chủng ASFV phát hiện tại Việt Nam được so sánh đặc điểm di truyền để xác định kiểu gene với các chủng được phát hiện ở các nước trong khu vực như: Trung Quốc, Madagascar, Georgia, $\mathrm{Nga}$, Triều Tiên và Hàn Quốc. Kết quả cho thấy rằng tất cả các chủng này có cùng một phân nhánh thuộc kiểu gene II. Do đó, có thể khẳng định rằng virus thuộc kiểu gene II là lưu hành phổ biến ở Châu Á và có nguồn gốc từ Madagascar (Châu Phi) sau đó lây lan sang Georgia vào năm 2007. Georgia là một quốc gia thuộc vùng Caucasus của Âu - Á, nằm ở ngã ba của Tây Á và Đông Âu, giáp với Nga về phía Bắc nên virus có thể lây lan vào Irkutsk, Nga cũng trong năm 2007. Nga có biên giới giáp với Trung Quốc nên có thể virus thuộc kiểu gene II này có thể xâm nhập vào Trung Quốc thông qua con đường thương mại, vận chuyển heo và sản phẩm heo vào năm 2018 (FAO, 2018). Sự bùng phát ASF tại Việt Nam được xác định xảy ra đầu tiên là ở khu vực phía Bắc, gần biên giới Việt Nam - Trung Quốc, nơi có việc vận chuyển, mua bán trái phép heo và các sản phẩm từ heo qua biên giới (FAO, 2018). Do đó, dựa vào những yếu tố trên có thể khẳng định rằng sự xuất hiện của ASFV tại Việt Nam là có nguồn gốc từ Trung Quốc. Đồng thời, từ kết quả trên cho thấy các chủng ASFV xuất hiện tại Việt Nam, Trung Quốc và các nước châu Á đều thuộc genotype II.

\section{KẾT LUẬN}

Bệnh dịch tả heo Châu Phi gây tổn thất to lớn đến chăn nuôi heo ở huyện Phú Tân, 18/18 xã và thị trấn trên đại bàn huyện đều xuất hiện ổ dịch ASF và $27,34 \%$ tổng đàn heo của huyện bắt buộc phải tiêu hủy do nhiễm bệnh. ASFV hiện diện trên đàn heo huyện Phú Tân, tỉnh An Giang thuộc genotype II, cùng genotype với ASFV phát hiện đầu tiên ở Việt Nam tại Hưng Yên và tất cả chủng phát hiện ở Việt $\mathrm{Nam}$, và trong cùng phân nhánh với $\mathrm{ASFV}$ lưu hành phổ biến ở Châu Â và Châu Âu.

\section{TÀI LIỆU THAM KHẢO}

Alcamí, A., Carrascosa, A.L. \& Viñuela, E. (1989). The entry of African swine fever virus into Vero cells. Virology, 171(8), $68-75$.

Bastos, A. D. S., Penrith, M. L., Cruciere, C., Edrich, J. L., Hutchings, G., Roger, F., Couacy-
Hymann, E. \& Thomson, G. R. (2003).

Genotyping field strains of African swine fever virus by partial $\mathrm{p} 72$ gene characterisation. Archives of Virology, 148(14), 693 - 706.

Bao, J., Wang, Q., Lin, P., Liu, C., Li, L., Wu, X., Chi, T., Xu, T., Ge, S., Liu, Y., Li, J., Wang, S., Qu, H., Jin T. \& Wang Z. (2019). Genome comparison of African swine fever virus China/2018/Anhui XCGQ strain and related European p72 Genotype II strains.

Transboundary and Emerging Diseases, 66(10), 1167 - 1176.

Beltrán-Alcrudo, D., Gallardo, M. A. A. C., Kramer, S. A., Penrith, M. L., Kamata, A. \& Wiersma, L. (2017). African swine fever: detection and diagnosis - A manual for veterinarians. http://www.fao.org/3/i7228e/i7228e.pdf

FAO. (2018). African swine fever threatens people's republic of China - A rapid risk assessment of ASF introduction No. 05.

http://www.fao.org/documents/card/en/c/I8805EN/

King, D. P., Reid, S. M. , Hutchings, G. H., Grierson, S. S., Wilkinson, P. J., Dixon, L. K, Bastos, A. D. S. \& Drew, T. W. (2003). Development of a TaqMan ${ }^{\circledR}$ PCR assay with internal amplification control for the detection of African swine fever virus. Journal of Virological Methods, 107(1), 53-61.

Montgomery, R. E. (1921). On a form of swine fever occurring in British east africa (Kenya Colony). Journal of comparative pathology and therapeutics, 34, 159-191.

Phan Thị Hồng Phúc, Nguyễn Thị Thùy Dương, Trần Xuân Đông \& Đặng Thị Thư. (2020). Nghiên cứu tình hình bệnh dịch tả lợn Châu Phi tại tỉnh Quảng Ninh. Khoa học Kỹ thuật Thú y, 27(5), 12-19.

Quembo, C. J., Jori, F., Vosloo, W. \& Heath, L. (2017). Genetic characterization of African swine fever virus isolates from soft ticks at the wildlife/domestic interface in Mozambique and identification of a novel genotype.

Transboundary and Emerging Diseases, 65(2), 420-431 https://doi.org/10.1111/tbed.12700

Thompson, J. D., Higgins, D. G. \& Gibson, T. J. (1994). CLUSTAL W: Improving the sensitivity of progressive multiple sequence alignment through sequence weighting, positions-specific gap penalties and weight matrix choice. Nucleic Acids Research, 22, 467-468.

Trạm Chăn nuôi và Thú y huyện Phú Tân. (2019a). Báo cáo tình hình thực hiện công tác phòng, chống bệnh Dịch tả heo Châu Phi huyện Phú Tân (Số 157/BC-BCĐ ngày 31/10/2019).

Trạm Chăn nuôi và Thú y huyện Phú Tân. (2019b). Báo cáo số liệu đàn heo hiện có trên địa bàn 
huyện Phú Tân (Số 196/BC-TCNTY ngày 01/7/2019).

Trần Thanh Dũng. (2020). Ảnh hưởng của dịch tả heo Châu Phi đến hoạt động chăn nuôi nông hộ tại huyện Long Mỹ, tỉnh Hậu Giang. Tạp chi Khoa học Nông nghiệp Việt Nam 2020, 18(10), 828-838.

Trương Văn Hiểu, Trần Ngọc Bích, Nguyễn Thị Kim Quyên, Nguyễn Phúc Khánh, Lê Quang Trung, Trần Duy Khang, Đỗ Thị Thùy Trang và Nguyễn Minh Dũng. (2020). Khảo sát các yếu tố nguy cơ và sự lưu hành của virus dịch tả heo Châu Phi tại tỉnh Bến Tre. Tạp chí Khoa học kỹ thuật Thú y, 3(17), 5-13.

Van Phan Le, Dae, G. J., Yoon, S. W., Kwon, H. M., Trinh, T.,B.,N., Nguyen, T. L., Bui, T. T. N., Oh, J., Kim, J. B., Cheong, K. M., Tuyen, N. V., Bae, E., Vu, T. T. H., Yeom, M., Na, W. \& Song, D. (2019). Outbreak of African Swine Fever, Vietnam, 2019. Emerging Infectious Diseases, 25, 1433-1435.

OIE. (2012). Manual Diagnostic Tests Vaccines for Terrestrial Animals, Chapter 2.08.01: African swine fever.

https://doi.org/10.1002/9781119350927.ch25 